\title{
Frugal innovation beyond emerging countries: the key role of developed countries
}

\section{Marcos Rogério Mazieri}

Doutor em Administração de Empresas . Bacharel em Administração, pela Associação Internacional de Educação Continuada, pós-graduação MBA em finanças, pela Fundação Getulio Vargas de SP , pós-graduação MBA em captação de financiamentos, pela Associação Internacional de Educação Continuada, pósgraduação MBA em marketing, pela Fundação Getulio Vargas de SP, São Paulo, Brasil marcosmazzzieri@gmail.com

Leonardo Vils

Graduação em Bacharel em Ciências Econômicas pela Universidade Cândido Mendes . Mestre em Administração de Empresas pela Universidade Nove de Julho . Professor do Programa Mestrado Profissional em Gestão Ambiental e Sustentabilidade na Universidade Nove de Julho, São Paulo, Brasil vilsleo@gmail.com

Maurício Jucá de Queiroz

Doutor em Administração pela Universidade de São Paulo, Mestre em Administração pela Universidade de São Paulo, Graduado em Administração pela Universidade de São Paulo Coordenador do curso de graduação em Administração de Empresas da FACAMP - Faculdades de Campinas. Atua como professor de graduação e pós-graduação, e coordenador da área tecnológica em Marketing do Semead.

mauricio.queiroz@facamp.com.br

\section{Editor Científico: José Edson Lara}

Organização Comitê Científico

Double Blind Review pelo SEER/OJS

Recebido em 04.12.2017

Aprovado em 19.12.2017

\footnotetext{
Este trabalho foi licenciado com uma Licença Creative Commons - Atribuição - Não Comercial 3.0 Brasil
} 


\section{Abstract}

Frugal innovation is no longer relevant only for emerging countries or for low-tech artifacts. The interest of countries developed by frugal innovation has been increasing in recent years, since it is an alternative of less use of natural and financial resources, however, it is not clear which is the role of developed countries in the advancement of frugal innovation. In this article, we examine the literature, technical reports and patents to propose some possible paths. Through qualitative methods such as semantic analysis, we argue that research for the modification of the technological matrix of products, processes and organizational arrangements and the development of a better understanding of the frugal entrepreneur may be key roles for developed countries to contribute to the development of frugal innovation.

Keywords: Frugal innovation; Emerging countries; Patent; Innovation.

\section{Inovação frugal além dos países emergentes: o papel fundamental dos países desenvolvidos}

\section{Resumo}

A inovação frugal não é mais relevante apenas para países emergentes ou para artefatos de baixa tecnologia. $O$ interesse dos países desenvolvidos pela inovação frugal tem vindo a aumentar nos últimos anos, uma vez que é uma alternativa de menor uso de recursos naturais e financeiros, no entanto, não está claro qual é o papel dos países desenvolvidos no avanço da inovação frugal. Neste artigo, examinamos a literatura, os relatórios técnicos e as patentes para propor alguns caminhos possíveis. Através de métodos qualitativos, como a análise semântica, argumentamos que a pesquisa para a modificação da matriz tecnológica de produtos, processos e arranjos organizacionais e o desenvolvimento de uma melhor compreensão do empreendedor frugal podem ser papéis fundamentais para que os países desenvolvidos contribuam para o desenvolvimento de inovação frugal.

Palavras-chave: Inovação frugal; Países emergentes; Patente; Inovação.

\section{Innovación frugal además de los países emergentes: el papel fundamental de los países desarrollados}

\section{Resumen}

La innovación frugal ya no es relevante para los países emergentes o para los artefactos de baja tecnología. El interés de los países desarrollados por la innovación frugal ha venido aumentando en los últimos años, ya que es una alternativa de menor uso de recursos naturales y financieros, sin embargo, no está claro cuál es el papel de los países desarrollados en el avance de la innovación frugal. En este artículo, examinamos la literatura, los informes técnicos y las patentes para proponer algunos caminos posibles. A través de métodos cualitativos, como el 
análisis semántico, argumentamos que la investigación para la modificación de la matriz tecnológica de productos, procesos y arreglos organizacionales y el desarrollo de una mejor comprensión del emprendedor frugal pueden ser papeles fundamentales para que los países desarrollados contribuyan al desarrollo de innovación frugal.

Palabras clave: Innovación frugal; Países emergentes; Patente; Innovación.

\section{Introduction}

Interest in frugal innovation originating in the southern hemisphere of the planet, especially in India, has surpassed the status of innovation at the bottom of the pyramid since the early part of 2010. Although frugal innovation remains an alternative for countries in restraint or resource scarcity (emerging or transition countries), studies of frugal innovation in developed country contexts have been published by practitioners and scholars. The naive innovation, based on improvisation, as conceived initially from the years 2000 , has come to be perceived as relevant also for the developed countries like United States, France, England and Germany. The relevance given by developed countries to frugal innovation has followed two theoretical antecedents, especially theories of innovation management or entrepreneurship, involving the creation of solutions by community innovators, as it happens in emerging and transition countries. Both in the context of emerging countries and in developed countries, frugal innovation can be defined as a substantial change in a particular product, process, organizational arrangement, marketing or business model that results in drastic cost reduction and social inclusion. Frugal innovation is not a type of innovation, but a pattern of response to a particular problem situation (Mazieri, 2016). In this way, frugal innovation can coexist with other types of innovation such as incremental, radical, architectural and modular innovations (Henderson \& Clark, 1990).

In the studies on frugal innovation, case studies are predominant, usually exploratory. The contributions of the articles are aimed at broadening the understanding of how a given subject, community or company has developed some type of innovation that by changing the matrix of resources can be considered a frugal innovation. Normally, in the sections of the final considerations of these articles, some propositions from the case study are offered, as well as research agendas that recommend empirical studies to develop integrated visions or 
frameworks to better understand frugal innovation. In the same sections of final considerations, there are still doubts as to how frugal innovation is perceived outside Africa or Asia, especially since the most publicized case studies originate in India and China. More specifically, I can infer that the case studies focus on two more frequent approaches: (i) presenting artifacts developed by the community that have become relatively widespread and economically viable, (ii) presenting products from multinational MNC companies, which have developed products for neglected markets. India and China are the two most populous countries in the world with 1.2 billion and 1 billion people respectively, which has the predominance of the rural population in common. Usually, these artifacts, whether of local origin or of external origin (external to the country of origin), have the purpose of serving the rural population, thus forming, the formation of a new market, consumer market.

Therefore, the purpose of this article is to analyze the accumulated knowledge about frugal innovation besides its incidence in the emerging countries. Specifically, analyze the contributions of information in general, patent information, creativity and serendipity. It is also proposed to change the technological matrix of products and processes as the key role of developed countries as a contribution to the development of frugal innovation. For this analysis, I used automated content analysis methods, both in scientific articles and in professional reports, as well as in patent documents, as a point of triangulation of the reflections coming from the literature review. Patents are, in this context, records of the expectation of innovation of their depositors (Reymond \& Quoniam, 2016).

\section{Frugal innovation and information}

Information is for innovation, as the raw material is for industrial production (Nocera, 2012). The innovations go through phases, whose systemic vision has been called by the scientific literature as Structured Innovation. Since this is a systemic view, in the structured view of innovation there are input, control and output structures. Information is the interpretation of the codification given to the data (Lal, 2000). Data are symbols, which represent certain circumstances, phenomena, facts, be they physical, chemical or behavioral. When assigning certain order and codes to these symbols, one has the information. The only formal aspect of information is not 
discussed here, but rather the broader meaning of collecting, organizing, analyzing and interpreting information, even if this process is manual, intuitive and informal.

The information and its relations with the processes of frugal innovation was not explored in the works of Radjou, Prabhu, Ahuja (2012) or Bhatti (2012) in their models on the principles of Frugal Innovation, directly. In the models proposed by Radjou et al. (2012) and Bhatti (2012), the use of information is implied or presented in an encapsulated form in some of its dimensions, without presenting it as an aspect of great relevance, which ends up being contradictory when the case studies of these authors are presented. What I see in most of the cases presented by the authors is that the Frugal Innovation processes are triggered by the observer's posture in the face of adversity, which then draws on the skill, creativity and serendipity to, from the information obtained from the observation of the context, find some viable solution.

In investigating the process of structured innovation, I observe that the inventive cycle happens in a very similar way, that is: the inventor observes a problem or objective situation to be achieved and by applying scientific research methods or structured methods performs the research trajectory and development to discovery or invention. Comparing macro processes, frugal innovation, and structured innovation, it remains clear that, whether informally or formally, information is antecedent to the phenomenon of discovery or invention. Invention is the discovery that has not yet been made available to the market and has not gone through the process of diffusion and adoption (Quoniam, Kniess, \& Mazieri, 2014). According to Bregonje (2005), when information is applied, it becomes knowledge. One can then make the analogy that the information applied to the solution actions of a problem produces the discovery or the invention in a certain institutional environment. 


\subsection{Frugal innovation and institutional voids}

Institutional environments are those delineated by legal and legal formatting of countries, regions and organizations (Xu \& Meyer, 2012). Institutional restrictions are all those legal and legal conditions that generate negative effects in the development of enterprises, businesses or even the quality of life of the people of a certain place. In this aspect, the absence of laws, norms and negligence in governmental action also has the negative effect described above, presenting behaviors similar to the effects of institutional restriction (Meyer, Estrin, Bhaumik \& Peng, 2009; Xu \& Meyer, 2012). As taught by (Cavusgil, Ghauri \& Akcal, 2012), emerging countries are those that present substantial GDP growth, direction to the market economy and reduce government interference in the economy, however, institutional constraints are quite frequent in these markets. Meyer et al. (2009) argues that emerging countries or emerging economies in this study treated as synonyms are especially characterized by inefficient markets, active government involvement in the economy, extensive business networks and great uncertainty.

In the first analysis, the assumptions made by Cavusgil (2012) and Meyer et al. (2009) differ widely, however, when the conditions of the business environment are observed, both are consonants. Meyer et al. (2009) describes the environment, according to research conducted by the World Bank in a two-year inventory service called the World Business Environment Survey (WBES), where the state is empirically verified in the institutional environments of emerging countries. Cavusgil et al. (2012) describes the emerging country concept, according to rating agencies, which therefore use particular criteria to classify them. The Cavusgil classification (2012) uses longitudinal analysis and the Meyer et al. (2009) study presents the point analysis, cross section being, therefore, the two complementary works.

In the context of Frugal Innovation, according to the literature consulted (Agarwal \& Brem, 2012; Brem \& Ivens, 2013; Leliveld \& Knorringa, 2017; Pansera \& Sarkar, 2016; Tiwari \& Herstatt, 2014), adversity and extreme need led to the emergence of frugal innovation. What we want to consider in this current study is that institutional constraints and voids, notably influential in the quality of life and the development of market conditions in emerging countries can appear as adversities. 


\subsection{Frugal innovation and resource scarcity}

In contemporary society, the mechanisms and strategies adopted to perpetuate a lifestyle may have caused a great imbalance in climatic conditions, as well as reducing the availability of some natural resources, such as water (Levanen et al., 2016). In this regard, the reduction of resource availability affects all countries, albeit more strongly the emerging countries. The interest of large Western organizations like General Electric or even Renault in frugal innovation is not something visionary but survival. The possibility of accessing new markets, still unassisted or neglected, and the view that in 10 or 20 years certain raw materials, currently common and used in the products of these companies, may not be available, places frugal innovation as one of the possibilities of giving "next step" from the point of view of continuity of these companies.

Finding solutions with other resources or with fewer resources seems to be a necessity for some industries. At this point, the scarcity of resources presents to different degrees for developed and emerging countries, the latter being more sensitive to this scarcity. Radjou et al. (2012) states that the lack of resources has practically forced emerging countries to seek alternatives, notably frugal innovation. The author himself classifies frugal innovation as a de-globalization.

Bhatti's approach (Bhatti, 2012a), chose the separate explanation of the terms innovation and frugal, before presenting the meaning of the associated words, which will be retained in this current article. Bhatti argues that frugal is something economic, which presents only the essential, which is characterized by or reflects the economy in the use of resources (Bhatti, 2012). The seminal work of Lastovicka, Bettencourt, Hughner \& Kuntze (1999) for the definition of frugality, found the of the term "frugal" for use in applied social sciences. In the study, the findings of the frugal term were usually associated with religious themes, self-help, aspects related to being economic or to psychological perspectives.

Frugality was used in the early twentieth century in America as part of the philosophy of some religions, which related frugality to sacrifices for some goal Lastovicka et al. (1999). It seems that the relation of the term frugal or frugality with sacrificial episodes has built the belief that something frugal may be inferior to something non-frugal, although such fact has not been found in the researches, even though the subject belongs to a field of recent knowledge (Bhatti \& Ventresca, 2013), 
on the contrary, Bhatti states that frugal is not cheap but rather of higher performance. For Nash (1991), frugality is the choice of "ethical consciousness" or the intentional behavior of responding to ecological and social conditions before production and consumption (Nash, 1991). The alignment of the concept of social and ecological consciousness with frugality can better explain the adherence of these models to developing and underdeveloped markets, even though frugal behavior is a response to a contingency of resources, to the institutional vacuum or market reach instrument of the "pyramid base" BOP (Prahalad, 2002).

\subsection{Frugal innovation, reverse innovation and open innovation}

Frugal innovation is the overcoming or diversion of resource constraints and institutional gaps to create more markets by inclusion (Bhatti, 2012). The University of Santa Clara, California, is one of the pioneering universities in engineering education based on frugal innovation and therefore relevant to bring the definition recognized by the same regarding the subject in question. For the University of Santa Clara, California, Frugal Innovation is a problem-solving method, a "game change" strategy that addresses the needs for products and services originating in emerging and underdeveloped markets, whose main characteristics are related to economizing, saving, simplifying, being careful, using productive chains and low-cost raw materials, emphasizing sustainable practices and the philosophy of "doing more with less" (http://www.scu.edu/engineering/frugal/about/). It understands Frugal Innovation strongly linked to social justice, but not in the aspect of doing well but integrating the vision of Frugal Innovation through a holistic approach incorporating altruism with the business result. By interpreting the OECD definitions of innovation and the definitions of Frugal Innovation one can seek to merge the concepts as something substantially new or improved in products, processes, marketing or organizational arrangements that aim for greater accessibility, economic viability, adaptability and convenience for companies not yet reached or not served by structured innovation.

Frugal Innovation occurs in the local institutional context (Bhatti, 2012), which may explain the difficulty in extrapolating its models or results to something like mass production. Even if the models are used, there is usually a need to adapt to the local 
institutional context in which the model will be applied. The paradox is that according to Bhatti (2012), Frugal Innovation is also about finding a scalable and sustainable way of offering the novelty that will not necessarily pass through the processes of protection through trademarks or patents, common in developed countries. For these institutional environments in emerging and transition countries, patents can be used as sources of information rather than protection of intellectual property.

\subsection{Frugal innovation and patent}

Patents are presented as unique sources of information since the technological results presented to carry out the patent application are rarely replicated in other publications (Barroso, Quoniam, \& Pacheco, 2009). The various offices responsible for patent applications are freely accessible from the public via the internet and maintain databases with full descriptions of the inventions submitted for filing. These patents, whether or not approved, as well as the description of the inventions in functional and application terms remain available and visible to the public forming a large technological library (Dou, 2009).

On the availability and usefulness of this knowledge contained in patent information, there are studies that examine the ways in which its practical use, decoding and analysis can be used to help solve the problems of companies, communities, public sectors and developing countries (Bregonje, 2005; Fleming \& Sorenson, 2001), as well as their use as indicators of $R \& D$ investment levels, technological trends, estimates of public and private investments to support decisions in several industries such as low carbon, photovoltaic and electricity generation (Breyer, Birkner, Meiss, Goldschmidt, \& Riede, 2013; Kim, Kim, \& Flacher, 2012; Wiesenthal, Leduc, Haegeman \& Schwarz, 2012), highlighting the multidisciplinarity and relevance of the information present in this database for $\mathrm{R} \&$ and innovation.

The use of the IPC is one of the main means for the use of knowledge since it allows, in addition to the functional understanding and application of this technological information contained in the patent, to promote interoperability with other informational bases, such as scientific articles (Dou, 2009). Assuming the availability and free use of patent information, it is necessary to understand how information is stored in patent office databases as described, interrelated and codified (Tseng, Lin, \& Lin, 2007; Tian, Zhiping, \& Zhengyin, 2013; Yang, 2005). 
Coding in these technology repertoires generates a universal language (International Patent Classification - IPC), which needs to be "translated" into the common language so that it can take possession of its benefits. These benefits, in general, are linked to the possible solutions of technological problems faced in the daily routines of organizations, communities and supply chains in their diverse needs for practical knowledge expansion (Mgbeoji, 2001), such as waste reduction and reuse, expansion productive capacity, environmental protection, social inclusion, among others.

\section{Semantic analysis in frugality detection}

One of the ways to identify certain patterns in textual documents is content analysis. The concept of text corpus in this research consists of the grouping of " $n$ " unique texts that can be classified from certain points of homogeneity, which identifies them as parts of the same "o" object. The texts, which make up the corpus of analysis, are produced in two ways. One of the ways of producing such texts is through the answers to questionnaires of semi structured or open interviews. The answers to these questionnaires generate a verbal description that can be converted to textual description through the transcription process. The other way is to retrieve texts produced by other sources (literature, newspaper news, scientific articles, and non-exhaustive patents) that are already codifying thoughts and ideas in textual form. In the latter case, when texts already produced by sources other than an interview defined by the researcher are used, there is less possibility of an interpretative bias, as if such data had been found in "nature" for an analysis. Although it is not an epistemological discussion, it should be emphasized that when the textual analysis method is used in secondary data, even if interpretation techniques are used in some stages, this method of textual analysis seems to be approaching a positivist view.

The text segments are excerpts from texts, usually with three lines that form a lexical context. The lexical Context is known in different ways depending on the field of study. In social representation, they are known by indicators of theories and knowledge (Camargo \& Justo, 2013) and in linguistics are known by semantic contexts. In this current research, classes are defined as lexical contexts or as semantic contexts and it can be assumed that these contexts form the classes. 
Classes are partitions that express the common meanings of the thought of the text's producers. In the case of patents, the focus was to analyze the abstracts.

Abstracts are texts written by the inventors who claim the patent, where it is sought to express what or which problems the invention proposes to solve. In examining, for example, ten (10) patents deposited by different inventors, but on the same technology, the segments of texts formed and the consequent defined classes will be those that will group the common ideas present in the ten (10) patent applications whose point of homogeneity is technology (10 patents on the same technology).

Words are the fragments that carry the senses of the ideas of the producer of the text, so the analysis of the frequency of words is what makes it possible to compose the segments of text. Segments of texts are therefore composed of words used by the text's producer when it was intended to express an idea or thought. In the case of abstracts analysis of patents, the words used by the inventor carry the technical and technological message that can be interpreted to identify adjacent details such as the environment where the invention was given, the type of proposed innovative change and even the social concerns like. The set of words or forms, as they are called in the universe of textual analysis, define vocabularies.

\subsection{Lexical class or semantic class: the way to understand the technological matrix}

As described, the text segments comprise the parts of a text. Its division is provided by the use of the first part of the algorithm ALCESTE. The method proposed by Reinert (Reinert, 1990b) goes beyond the algorithm of separating texts into text segments, providing a descending hierarchical classification (CHD). The descending hierarchical classification consists of performing Chi2 (chi-square) texts using the frequency of words within the text segments as a score, comparing them with other text segments. Through these Chi2 tests of the text segments, the text segments are grouped into classes. Classes are aspects of a representation or the interlacing of aspects (Camargo et al., 2013).

Segments of text that have vocabulary common to each other and different between classes form lexical classes or semantic classes. They are grouped by exhaustive Chi2 tests that produce scores that are later definitively and permanently separated (Reinert 1990b, 1990a, 1995, 2001, 2007). In terms of computational 
strategy, it is a classification of forms (vocabulary) considering the frequency of words in said segments of texts. In Reinert (1990), when analyzing the literature, in an interpretive view, he recognized in the classes the "notion of the world" as a perceptual-cognitive frame with a certain temporal stability associated with a complex environment. For the field of linguistics and communication, the semantic class are understood as lexical fields or semantic contexts that demonstrate the nuances of language. In the field of social representation, given the view that this field confers the linguistic manifestation, semantic class present theories and knowledge of common sense, or, as Professor Camargo (2013) teaches, semantic class are fields of images about a given object, or even aspects of the same representation. For the analysis of patents, specifically for the analysis of the text that forms the abstract, the interpretative vision of Reinert (1990) seems to have adherence, grounding the proposal of an interpretative view of abstracts of patents. In the context of the analysis of patent abstract, semantic class are perceptual-cognitive descriptions of a technical or technological response to a problem. They can indicate an association between a solution of a given problem and a geographic region at a given point in time. Thus, classes will be homogeneously separated in terms of the central concept (Henderson \& Clark, 1990). Considering these methodological assumptions, when analyzing a patent summary, it will be possible to recognize and characterize the technical or technological solution sought by the inventor, especially related to the function (for what purpose) and application (where to use) of the invention, as can be done by analyzing the IPC codes. However, using the text mining method in patent abstracts, one can achieve the interpretive view on the central concept and the perceived adjacent social issues.

In this view, the "idea" is the representation of the result of a cognitive process; therefore, the idea is a cognitive representation of response (technical or technological solution) that considers certain characteristics of the context where the problem was perceived. This cognitive representation of response addresses ways of overcoming an obstacle within the reach of a social need or desire, called simply a problem. Finally, the problem is a relative material-social representation, of a certain level of perceived obstacle, separates a given present state from a future state. The future state can be triggered by a desire (usually with responses in the Structured Innovation Model) or an essential need (Frugal Innovation model response). 
Semantic class are presented by dendograms, which reflect the Descending Hierarchical Classification, which can be explored in terms of their contents (segments

of texts).

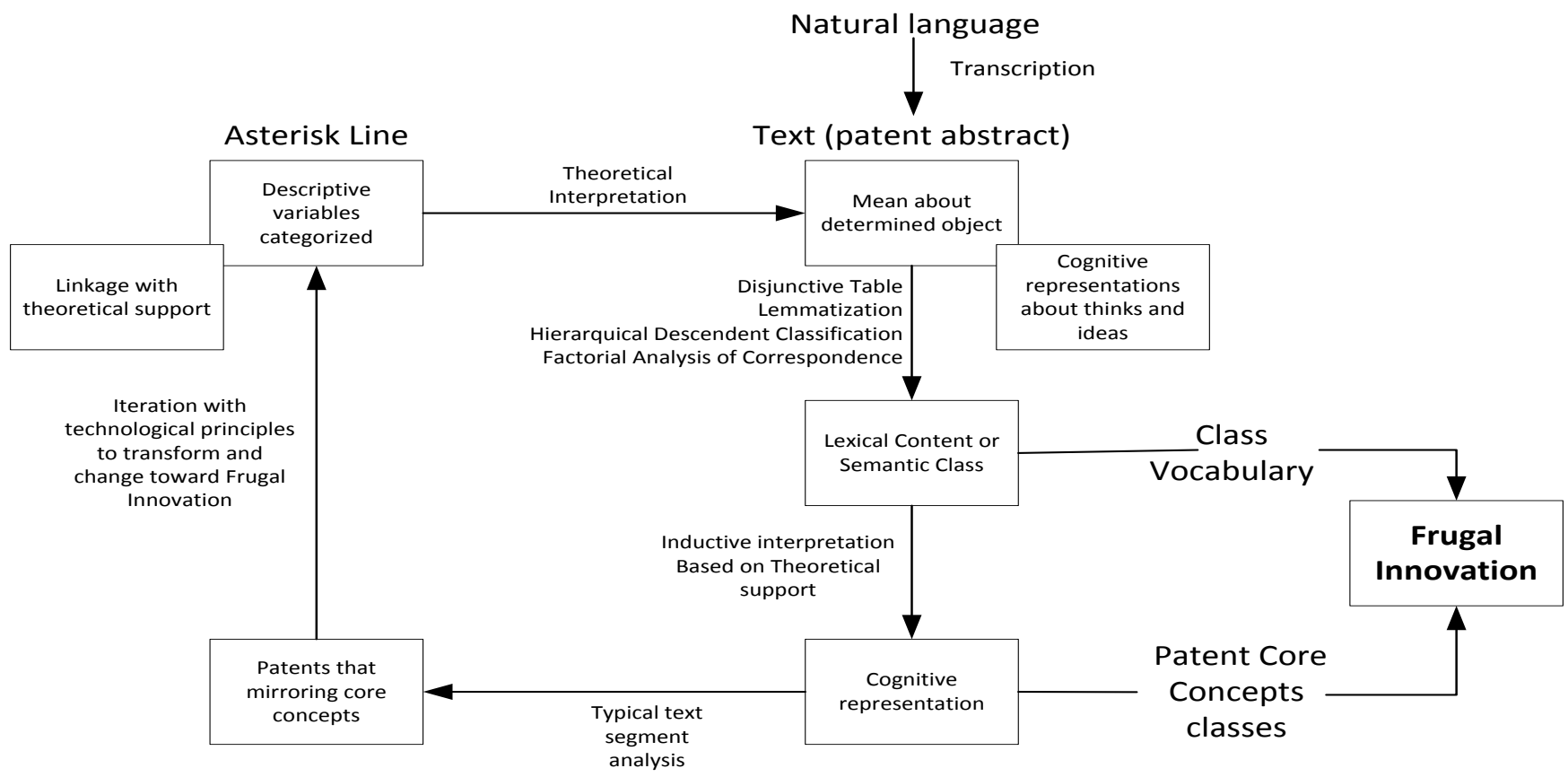

Figure 1

Methodological approach to integration of frugal innovation and patents Fonte: Author, 2017.

\section{Discuss}

Frugal Innovations are changes in products, processes, organizational or marketing arrangements developed with drastic reduction in the use of resources (financial, natural, temporal and human) combined with drastic increase in social inclusion (Mazieri, 2016). Historically the social needs and difficulties have been triggers of the activities of innovation. The drastic reduction in the use of resources is one of the dimensions of Frugal Innovation (Mashelkar, 2012; Prahalad \& Mashelkar, 2010a; Prahalad \& Mashelkar, 2010b). The drastic increase of social inclusion is the other fundamental principle. The development of these fundamental principles leads to the reduction of the prices of a product or service, an important factor for increasing accessibility and consequently for social inclusion (M. Zeschky, 
Widenmayer, \& Gassmann, 2011a, 2011b, 2014; Marco B. Zeschky, Winterhalter, \& Gassmann, 2014; M.B. Zeschky, WinterhalterProf, \& Gassmann, 2014).

It is not by chance that the contingencies and constraints in emerging countries seem to have contributed to the development of a distinct way of "finding solutions" and "solving problems." Initially, solving problems without stopping the minimum conditions in terms of knowledge or resources may seem inadequate, but when survival depends on such a solution, these solutions legitimize themselves, precisely because there are no alternatives. The scarcity of resources delineates an environment of opportunity, if we consider these aspects. Thus, emerging countries have been gaining ground in studies that involve management, innovation, and economic development. The emerging market potential of emerging countries in the context of Frugal Innovation is the combination of rising purchasing power of families (although they remain well below developed markets) and the number of people living in those 46 countries, classified as emerging countries.

Frugal Innovation is not a new type of innovation. Frugal Innovation is considered as a form of response to the constraints observable in a certain cultural and social context that retains certain principles related to reduction in the use of resources and increase of social inclusion. It can be used with a troubleshooting method or a method to develop products and services for unattended or neglected markets, but it can also be used in developed countries. The deepening of the topic of Frugal Innovation aims to improve understanding to the point of identifying, classifying and reproducing it in a certain way in order to transfer knowledge to improve business performance. Frugal innovation has its roots in human need. It seems to be the most primitive and natural way of modifying something. Its root seems to be buried in the most basic human needs (Maslow, 1969) and perhaps the most basic of them: survival. Because of its essential nature, frugal innovation need not be perfect, but only useful within its simplicity and essentiality.

\subsection{Frugal innovation, creativity and serendipity}

A discovery can be achieved either voluntarily or involuntarily. Finding something we are looking for is one form of the phenomenon of discovery and finding something that is not sought is another form of discovery that depends on a different 
attitude from the first case; it is the attitude of serendipity. Serendipity is the sensitivity to perceive an unexpected outcome (Roberts, 1989). The definition presented serves as a clarifier of the term, evidencing the naive part of a discovery. When scientific research is carried out through the study and testing of propositions and hypotheses, if there is the alert attitude or attention of the researcher, unexpected results, if detected, may be more valuable than the study itself and the hypothesis itself. Therefore, in this study, following the teachings of Quoniam (2014) in class notes, serendipity is considered an attitude. A mental state of vigilance and attention to find something that has not been defined a priori (Foster \& Ford, 2003; Van Esch \& Feringa, 2000).

The main studies of Frugal Innovation (Bhatti, 2012, 2013; Prabhu, n.d.; Radjou et al., 2012; Rao, 2013) describe the presence of unexpected or naive discoveries that result in inclusion and accessibility solutions for populations, creating new markets and possibility of profitability by economies of scale. Serendipity would therefore be the attitude necessary for the frugal entrepreneur to take advantage of the opportunities that arise unexpectedly, while tracing their path towards a solution of problems. The focus of the structured innovation approach tends to neglect unexpected outcomes. In frugal innovation, unexpected results, if detected, may become important to achieve superior performance with the use of fewer resources or with the differentiated use of these resources. In this aspect, serendipity is considered a fundamental part for the best use of opportunities and resources, evidencing itself as a dimension of frugal innovation.

Creativity, characteristic of entrepreneurs (Filion, 1999) and frugal entrepreneurs, act as a propulsive attitude of the inventive process. Ideas and insights are structuring of propositions and hypotheses that must be investigated with some formal or informal method with serendipitous attention. Considering the findings of Bhatti (2012), the relations between the process of innovation and creativity and serendipity, could be graphically exposed as in the figure below. 


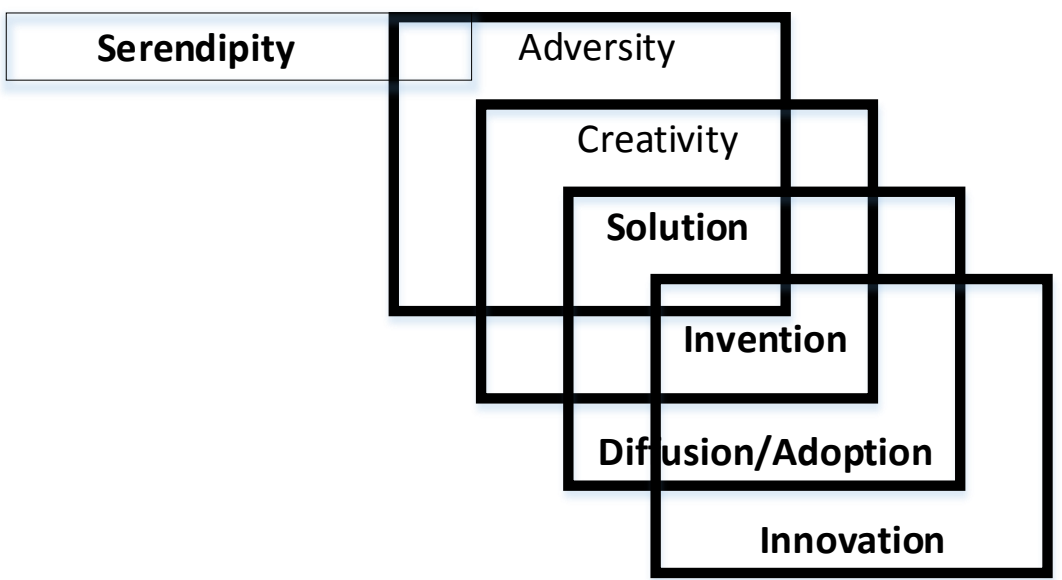

\section{Figure 2}

Creativity and serendipity in the innovation process

Fonte: Author, 2017

It can be seen that creativity and serendipity can be considered as mental attitudes that contribute to the innovation process, whether structured or frugal, whose differences would be in the mind set (Radjou et al., 2012) found consonant with the behaviorist Max Weber (1930). For the context of frugal innovation, creativity and serendipity, as attitudes, seem to be more important than the status of characteristics, being considered in this study as dimensions of frugal Innovation. Creativity and serendipity as mental attitudes, contribute to problem solving in environments with constraints or resource scarcity.

Analyzing the previous figure, it is observed that the trigger of creativity is adversity or necessity. Serendipity figures as responsible for the sensitivity the opportunities these adversities may pose (Radjou et al., 2012). Sensitivity, as explained, is the attitude of serendipity (Roberts, 1989). In this context, adversity seems to be very relevant to frugal innovation, having seen its emergence in environments of great constraints and scarcity. This may be the greatest obstacle to exploiting frugal innovation in developed countries, since it would be necessary to artificially reproduce the constraints (scarcity of institutional resources and obstacles) that trigger frugal thinking.

\subsection{Radical cost reduction}

Some classifications regarding cost and performance were proposed by Bhatti (2012), stating that frugal innovation is not something cheap, but something performance superior than the known performance on innovation, designed from the 
structured model. Performance addresses the relationship between resulting resources or outputs and applied resources or inputs. In the case of innovation, as discussed in the introductory chapters of this paper, the more resources applied at the entrance, the greater the amount of innovations resulting from the exit, as a positive economic impact, the "more is better" philosophy, process, more innovation in output. In the case of frugal innovation, there is a radically smaller application of resources at the entrance of the system to produce the innovations resulting from a strong economic and social impact, with radically lower prices, aiming at overcoming inaccessibility in the "less is more" philosophy ( the term "less is more," is used most often in Radjou's (2016) work in his book Jugaad Innovation, which serves as a reference both for the initial studies of frugal innovation, and for some MNC, such as Renault-Nissan). This philosophy, described in the works of Radjou et al. (Radjou et al., 2012) is one of the six mental ensembles designed and called in India by Jugaad. According to Radjou, Prabhu \& Ahuja (2012), Jugaad means in literal translation, discovery of something new, or correction of something, naively from adversity. Radju et al. Jugaad in some countries. In Brazil, the term "gambiarra" in China "zishu chuangxin", in the USA "D-I-Y", in Africa "jua kali" and in France the term "system D", are presented as synonyms of Jugaad, the Indian term. His studies address beyond the historical perspective of Jugaad Innovation or Innovation Jugaad in a free translation to Portuguese, presented in the chapter introducing this study, also mapping, through case studies, what he called Jugaad Innovation. According to Radjou et al. (2012), these are the common behaviors behind frugal innovators. Such studies are presented as relevant contributions to help in the investigation of frugal innovation, since it demonstrates and explains the mental set behind the frugal innovators in a consolidated way: Seek opportunity in adversity; Do more with less; think and act flexibly; keep simplicity; include the margin and think with the heart. It should be noted that Jugaad Innovation is not frugal innovation. The first is the mental set, often found in the people who develop Frugal Innovation, so they are features present in people or human resources, behind frugal innovations. Frugal innovation is therefore the product of the action of these human resources, the object, arising from thought based on the Jugaad mental set and certainly being the resultant object, revealing in itself certain characteristics and dimensions that can be better understood if understood before, the mental set Jugaad. 
Seek opportunity in adversity; According to Radjou et al. (2012) Kanak Das, a resident of a village in northeastern India has increased his bicycle tires to ride the bumpy, bumpy roads. More than accepting the fact that there were obstacles to the displacement, he made the restriction an advantage, and the bicycle with larger tires converts the shock with the ground in acceleration. Now, if the road is bumpier, the less force it has to do and the faster your bike moves.

Do more with less; Even practitioners of R \& D-based Innovation, whether in Western or Asian companies, whether developed or developing markets, discuss the scarcity of natural and financial resources. Silicon Valley investors are looking for ways to optimize the use of their financial resources, finding countless ways to analyze and decide on how much and who to invest. On the other hand, catastrophic predictions about the end of water availability, oil, climate change, melting of glaciers and other problems resulting from the reduction of the availability of natural resources around the globe are being reported in academic and journalistic circles. Of course, the waste of natural or financial resources has been condemned by both academics and practitioners of Innovation. Reducing the amount of raw material and production costs has therefore been mandatory throughout the global innovation ecosystem, including some adaptations of the LEAN Shingo System (2010) from the Toyota Production System (TPS) known as Lean Startup, used extensively by technology companies around the world, especially those located in Silicon Valley. At the heart of Lean Startup is reducing resource waste, simplifying the design process and delivering products based on flexibility and agility, so it seems to be able to be positioned in the Jugaad dimension of "doing more with less."

Think and act flexibly; According to Radjou (2012), Jugaad is the antithesis of the innovation approach in a structured way as those advocated by the Six Sigma method, for example. The more structured, the less flexible the system becomes, preventing rapid reactions from changes in the business environment. The entrepreneurs studied and who were responsible for the observed Frugal Innovations kept all known possibilities open without compromise with the standard, modifying business models, products and services based on the observations of the needs of communities, clients or even to identify imminent changes in the business or market environment. The Jugaad entrepreneur does not "think outside the box" (the English term used in the field of studies of creativity and serendipity: Think out of the box), 
but creates whole new boxes. It is non-linear thinking that leads to ideas and proposals for change that can transform markets and industries completely by disengagement with the status quo.

Maintain simplicity; Jugaad does not aim for sophistication or perfection based on engineering for example, but rather to find and develop what is good enough in each context truly. Creative simplicity is a key principle of Jugaad. Previously, in this study, the relationship between creativity and innovation was addressed, and the close relationship was clear. The mindset of the people involved with Frugal Innovation has similarities, so there is evidence that the mental set is a possible discriminating factor, with potential differences between the mental set of people involved in the process of developing innovations frugal and structured innovation.

With the studies of Radjou et al. (2012), evidence has been identified that creativity is an important part of the Jugaad mental set, which consequently makes it important also for frugal innovation. In Bhatti's (2012) study, when conceptualizing and theorizing frugal innovation, creativity does not appear explicitly. It is observed in the developed theory, in the model proposed by Bhatti (2012), that Jugaad is classified as element of the dimension of Schumpeterian Innovation, along with bricolage and reverse engineering. Such positioning is presented as a solution to the constraint and contingency of resources. Creativity does not appear in the theoretical model of Bhatti (2012) with key element status, as described by Radjou (2012). In this discussion, I am arguing for the repositioning of the creativity element, bringing it from within the Jugaad mental set to position it in the intersection area between Schumpeterian innovation, institutional innovation and social innovation. As I argue in this article, creativity may be a skill or an attitude and in the context of frugal innovation, it seems important to consider it as an attitude. Serendipity is an attitude, according to Quoniam, Kniess and Mazieri (2014). Creativity and serendipity are, therefore, complementary elements, involving competence, ability and attitude. In the words of Professor Quoniam (2013) "(...) he who finds what he seeks, does only a good job of school. Already the one who perceives something not expected and that has value, does research ". Creativity and serendipity as attitudes are elements formed by the mental set, positioning itself in the region of intersection between Schumpeterian, institutional and social innovation, if considered the model of Bhatti (2011), therefore, there is evidence that it is these attitudes are characteristic in people involved in frugal innovation. 
Include margin; Western organizations have their reason for being, serving the richer chains of consumers and customers, people who have purchasing power. In business analysis it is common to analyze the potential market, that is, how many people can be served as a product or service and how much money these people have to dedicate to said product or service. By this logic, obviously, if there are not people with sufficient financial resources, the business is not considered viable and is often not launched or produced. The Jugaad entrepreneur intentionally thinks of consumers and customers not yet served, so business analysis is different. The fact is that it creatively identifies how to create radical accessibility for non-traditional people and communities, not yet served, by creating inclusive business models engaging low-income people in nontraditional communities, not passively, but as cocreators of value.

Follow feelings; Jugaad innovators, do not have access to the focus group, nor do they make or buy market research to launch their products. Nor are they worried about what investors will think about their products or strategies. They know their products and consumers intimately, thus following their intuitions, empathy and passion. Day-to-day attentive observers with continuous contact with their consumers develop products based on local needs within local income conditions and market them relationally for the introduction of the product or service in the marketplace as defined by (Levitt, 1965) in the product life cycle. However, the cycle of adoption of innovations defined by Rogers (Rogers, 1976) has not yet been evidenced in the studies consulted for this study, and Bhatti (2011) has this as one of his research questions.

The contribution of patent information; the use of patent information as an accelerator of the problem-solving process can integrate a part of the frugal innovation process. Accelerating the problem solving process can reduce the cost of the solution, either by time saved or by avoiding rework. Another contribution of patent information is to represent the technological expertise available globally. By checking the technologies available in the patent information, it is possible to identify certain chemical, physical and behavioral principles, a fundamental part of the revision of the technological matrix of products and processes. The revision of the technological matrix is one of the frugal innovation design alternatives and may be 
the key role of developed countries in terms of contributing to the development of frugal innovation in a broad way.

Frugal Innovation as defined above, if analyzed from the perspective of the Jugaad mental set, can be described as the object resulting from the actions of the innovator Jugaad, or the entrepreneur Jugaad. It is the product of the actions of the human resources that acted according to the mental set Jugaad, which we pretend to call a frugal entrepreneur. The frugal entrepreneur may in this respect represent the opportunity to replicate frugal innovation in developed countries. The frugal entrepreneur can be trained and from it, even without the existence of restrictive institutional environments, structured innovation processes with the characteristics of frugal innovation could be developed, especially with a view to changing the technological matrix. By changing the technological matrix, I understand the return to the examination of the chemical, physical or behavioral principles that configure certain products, processes, organizational arrangements and marketing, with the aim of proposing substitute technologies that meet the same principles. This alternative is valid for developed countries, because they demand financial resources and sophisticated knowledge. It seems to be a key role of developed countries contributing to the breakthrough in frugal innovation, strengthening the initial positioning of which frugal innovation is distinct from philanthropy.

Frugal innovation can not be understood as part of the role of non-profit or charity activities (Bhatti \& Ventresca, 2012), although its results are economic and social. The fact of following some subjective guidelines such as empathy, intuition and emotion, very strange elements in the traditional business schools and that aim to maximize profit Frugal Innovation is not and hardly one day will be something that gives up the economic results and profits, especially due to the large scale always involved in this new ecosystem. It is not yet something that will only be useful and relevant to emerging or underdeveloped markets, but also to organizations rich in developed markets, since some aspects especially related to the scarcity of natural resources reach humanity in an integral way (Wiesenthal, Leduc, Haegeman, \& Schwarz, 2012; Xu \& Meyer, 2012).

\section{Conclusion and final remarks}

What I have observed in the researched literature on frugal innovation is that the use of information in creativity and serendipity are not directly mapped in the 
theoretical, conceptual or practical models consulted, which seems to mean their reduced importance in the frugal innovation process, such as it has been searched so far. In this article, I have argued for repositioning creativity to the center of the theme and for the development of attitudes of the frugal entrepreneur as a possibility to use principles of frugal innovation in structured innovation processes in developed countries. I also emphasized that the change in the technological matrix should be the key role of developed countries in frugal innovation.

\section{References}

Agarwal, N., \& Brem, A. (2012). Frugal and reverse innovation - Literature overview and case study insights from a German MNC in India and China. In 2012 18th International Conference on Engineering, Technology and Innovation, ICE 2012 Conference Proceedings. https://doi.org/10.1109/ICE.2012.6297683

Barroso, W., Quoniam, L., \& Pacheco, E. (2009). Patents as technological information in Latin America. World Patent Information, 31(3), 207-215. https://doi.org/10.1016/i.wpi.2008.11.006

Bhatti, Y. A. (2012). What is Frugal, What is Innovation? Towards a Theory of Frugal Innovation (SSRN Scholarly Paper No. ID 2005910). Rochester, NY: Social Science Research Network. Retrieved from http://papers.ssrn.com/abstract $=2005910$

Bhatti, Y. A., \& Ventresca, M. (2013). How Can 'Frugal Innovation' Be Conceptualized? (SSRN Scholarly Paper No. ID 2203552). Rochester, NY: Social Science Research Network. Retrieved from http://papers.ssrn.com/abstract=2203552

Bregonje, M. (2005). Patents: A unique source for scientific technical information in chemistry related industry? World Patent Information, 27(4), 309-315.

Brem, A., \& Ivens, B. S. (2013). Do Frugal and Reverse Innovation Foster Sustainability? Introduction of a Conceptual Framework (SSRN Scholarly Paper No. ID 2436833). Rochester, NY: Social Science Research Network. Retrieved from http://papers.ssrn.com/abstract=2436833

Breyer, C., Birkner, C., Meiss, J., Goldschmidt, J. C., \& Riede, M. (2013). A top-down analysis: Determining photovoltaics R\&D investments from patent analysis and R\&D headcount. Energy Policy, 62, 1570-1580. https://doi.org/10.1016/..enpol.2013.07.003 
Camargo, B. V., \& Justo, A. M. (2013). IRAMUTEQ: um software gratuito para análise de dados textuais. Temas Em Psicologia, 21(2), 513-518. https://doi.org/10.9788/TP2013.2-16

Cavusgil, S. T., Ghauri, P. N., \& Akcal, A. A. (2012). Doing business in emerging markets.

Sage.

Retrieved

from

http://books.google.com/books?hl=en\&lr=\&id=dtTGQ9|8RDYC\&oi=fnd\&pg=PP2\&d $\mathrm{q}=\% 22$ analysing+emerging+markets, +and+identifying\%22+\%22opportunities+for $\% 22+\% 22$ The+old+notion+that+developing+countries+are+inherently+risky\%22+ $\% 22$ as +over+80\% $25+$ of +the +world+population+resides+in+emerging $\% 22+$ \&ots $=$ PtMORPSN1\&sig=80qu9tRNStW5JI8arYtP U9JpDA

Dou, H. (2009). Palm Oil Strategy-General Considerations and Strategic Patent Analysis. Asia Pacific Journal of Innovation and Entrepreneurship 3(2), 75-93. Retrieved from http://s244543015.onlinehome.fr/ciworldwide/wpcontent/uploads/2011/05/apjie henri dou 2009.pdf

Filion, L. J. (1999). Empreendedorismo: empreendedores e proprietários-gerentes de pequenos negócios. Revista de Administração RAUSP Da Universidade de São Paulo, 34(2). Retrieved from http://www.rausp.usp.br/busca/artigo.asp?num artigo $=102$

Fleming, L., \& Sorenson, O. (2001). Technology as a complex adaptive system: evidence from patent data. Research Policy, 30(7), 1019-1039. https://doi.org/10.1016/S0048-7333(00)00135-9

Foster, A., \& Ford, N. (2003). Serendipity and information seeking: an empirical study. Journal of Documentation, 59(3), 321-340.

Henderson R. M., \& K. B. Clark (1990). Architectural Innovation: The Reconfiguration of Existing Product Technologies and the Failure of Established Firms. Administrative Science Quarterly, 35, 1.

Kim, J., Kim, Y., \& Flacher, D. (2012). R\&D investment of electricity-generating firms following industry restructuring. Energy Policy, 48, 103-117. https://doi.org/10.1016/..enpol.2012.04.050

Lal, K. (2000). Institutional Environment and the Development of Information and Communication Technology in India. Center for Research on Information Technology and Organizations. Retrieved from http://escholarship.org/uc/item/2724x6xi

Lastovicka, J. L., Bettencourt, L. A., Hughner, R. S., \& Kuntze, R. J. (1999). Lifestyle of the tight and frugal: Theory and measurement. Journal of Consumer Research, 26(1), 85-98.

Leliveld, A., \& Knorringa, P. (2017). Frugal Innovation and Development Research. The European Journal of Development Research, 1-16. https://doi.org/10.1057/s41287-017-0121-4 
Levanen, J., Hossain, M., Lyytinen, T., Hyvarinen, A., Numminen, S., \& Halme, M. (2016). Implications of Frugal Innovations on Sustainable Development: Evaluating Water and Energy Innovations. Sustainability, 8(1), 4. https://doi.org/10.3390/su8010004

Levitt, T. (1965). Exploit the product life cycle. Harvard Business Review, 43, 81-94.

Mashelkar, R. A. (2012). On building an inclusive innovation ecosystem. In Conference on Innovation for Inclusive Development.

Maslow, A. H. (1969). The farther reaches of human nature. Journal of Transpersonal Psychology, 1(1), 1-9.

Mazieri, M. R. (2016). Patentes e inovação frugal em uma perspectiva contributiva. Retrieved from http://bibliotecatede.uninove.br/handle/tede/1600

Meyer, K. E., Estrin, S., Bhaumik, S. K., \& Peng, M. W. (2009). Institutions, resources, and entry strategies in emerging economies. Strategic Management Journal, 30(1), 61-80. https://doi.org/10.1002/smj.720

Mgbeoji, I. (2001). Patents and Plant Resources-Related Knowledge: Towards a Regime of Communal Patents for Plant Resources-Related Knowledge. Xi, Wang, et al, Eds. <em>Environmental Law in Developing Countries: Selected Issues.</Em> Cambridge: IUCN Press. Retrieved from http://digitalcommons.osgoode.yorku.ca/scholarly works/1680

Nash, R. J. (1991). Three conceptions of ethics for teacher educators. Journal of Teacher Education, 42(3), 163-172.

Nocera, D. G. (2012). Can We Progress from Solipsistic Science to Frugal Innovation? Daedalus, 141(3), 45-52. https://doi.org/10.1162/DAED_a_00160

Pansera, M., \& Sarkar, S. (2016). Crafting Sustainable Development Solutions: Frugal Innovations of Grassroots Entrepreneurs. Sustainability, 8(1), 51. https://doi.org/10.3390/su8010051

Prabhu, N. R. (n.d.). What Frugal Innovators Do. Retrieved 25 March 2015, from https://hbr.org/2014/12/what-frugal-innovators-do

Prahalad, C. K. (2002). The Fortune at the Bottom of the Pyramid. Harvard Business Review, (9), 48-57.

Prahalad, C. K., \& Mashelkar, R. A. (2010a). Erfinderische Inder. Harvard Business Manager, 92-104.

Prahalad, C. K., \& Mashelkar, R. A. (2010b). Innovation's holy grail. Harvard Business Review, 88(7/8), 132-141. 
Quoniam, L., Kniess, C. T., \& Mazieri, M. R. (2014). A patente como objeto de pesquisa em Ciências da Informação e Comunicação. Encontros Bibli: revista eletrônica de biblioteconomia e ciência da informação, 19(39), 243-268.

Radjou, N., Prabhu, J., \& Ahuja, S. (2012). Jugaad Innovation: Think Frugal, Be Flexible, Generate Breakthrough Growth. John Wiley \& Sons.

Rao, B. C. (2013). How disruptive is frugal? Technology in Society, 35(1), 65-73. https://doi.org/10.1016/.t.echsoc.2013.03.003

Reinert, M. (1990a). Alceste une méthodologie d'analyse des données textuelles et une application: Aurelia De Gerard De Nerval. Bulletin de Méthodologie Sociologique, 26(1), 24-54. https://doi.org/10.1177/075910639002600103

Reinert, M. (1990b). Une méthode de classification des énoncés d'un corpus présentée à l'aide d'une application. Les Cahiers de l'analyse Des Données, $15(1), 21-36$.

Reinert, M. (1995). Quelques aspects de choix des unités d'analyse et de leur contrôle dans la méthode Alceste. JADT1995, 1, 27-34.

Reinert, M. (2001). Approche statistique et problème du sens dans une enquête ouverte. Journal de La Société Française de Statistique, 142(4), 59-71.

Reinert, M. (2007). Postures énonciatives et mondes lexicaux stabilisés en analyse statistique de discours. Langage et Société, (3), 189-202.

Reymond, D., \& Quoniam, L. (2016). A new patent processing suite for academic and research purposes. World Patent Information, 47, 40-50. https://doi.org/10.1016/i.wpi.2016.10.001

Roberts, R. M. (1989). Serendipity: Accidental discoveries in science. Serendipity: Accidental Discoveries in Science, by Royston M. Roberts, Pp. 288. ISBN 0-47160203-5. Wiley-VCH, June, 288.

Rogers, E. M. (1976). New product adoption and diffusion. Journal of Consumer Research, 2(4), 290-301.

Tian, L., Zhiping, Y., \& Zhengyin, H. (2013). The Large Aperture Optical Elements patent search system based on Domain Knowledge Organization System. World Patent Information, 35(3), 209-213. https://doi.org/10.1016/j.wpi.2013.04.007

Tiwari, R., \& Herstatt, C. (2014). Emergence of India as a Lead Market for Frugal Innovation. Retrieved http://www.cgihamburg.de/PDF/CGl Brochure Frugal Innovation 2014\%20\%20For\%20Website\%2001.pdf

Tseng, Y.-H., Lin, C.-J., \& Lin, Y.-I. (2007). Text mining techniques for patent analysis. Information Processing \& Management, 43(5), 1216-1247. 
Van Esch, J. H., \& Feringa, B. L. (2000). New Functional Materials Based on Self-Assembling Organogels: From Serendipity towards Design. Angewandte Chemie International Edition, 39(13), 2263-2266.

Weber, M. (1930). The Protestant ethic and the spirit of capitalism: Translated from the German by Talcott Parsons.

Wiesenthal, T., Leduc, G., Haegeman, K., \& Schwarz, H.G. (2012). Bottom-up estimation of industrial and public R\&D investment by technology in support of policy-making: The case of selected low-carbon energy technologies. Research Policy, 41(1), 116-131. https://doi.org/10.1016/..respol.2011.08.007

Xu, D., \& Meyer, K. E. (2012). Linking theory and context:'Strategy research in emerging economies' after Wright et al.(2005). Journal of Management Studies. Retrieved from http://onlinelibrary.wiley.com/doi/10.1111//.1467$\underline{6486.2012 .01051 . x / f u l l}$

Yang, D.-J. (2005). Multi-codec jukebox. Google Patents.

Zeschky, M. B., Winterhalter, S., \& Gassmann, O. (2014). From Cost to Frugal and Reverse Innovation: Mapping the Field and Implications for Global Competitiveness. Research-Technology Management, 57(4), 20-27. https://doi.org/10.5437/08956308X5704235

Zeschky, M. B., WinterhalterProf, S., \& Gassmann, O. (2014). From cost to frugal and reverse innovation: Mapping the field and implications for global competitiveness. Research Technology Management, 57(4), 20-27. https://doi.org/10.5437/08956308X5704235

Zeschky, M., Widenmayer, B., \& Gassmann, O. (2011a). FRUGAL INNOVATION IN EMERGING MARKETS. Research-Technology Management, 54(4), 38-45. https://doi.org/10.5437/08956308X5404007

Zeschky, M., Widenmayer, B., \& Gassmann, O. (2011b). Frugal Innovation in Emerging Markets: The Case of Mettler Toledo. Research-Technology Management, 54(4), 38-45. https://doi.org/10.5437/08956308X5404007

Zeschky, M., Widenmayer, B., \& Gassmann, O. (2014). Organising for reverse innovation in Western MNCs: the role of frugal product innovation capabilities. International Journal of Technology Management, 64(2-4), 255-275. https://doi.org/10.1504/IJTM.2014.059948 